\title{
Geological evolution of Mount Etna volcano (Italy) from earliest products until the first central volcanism (between 500 and 100 ka ago) inferred from geochronological and stratigraphic data
}

Stefano Branca - Mauro Coltelli - Emanuela De Beni • Jan Wijbrans

Published online: 19 January 2008

(C) Springer-Verlag 2008

Erratum to: Int J Earth Sci (Geol Rundsch)

(2008) 97:135-152

DOI 10.1007/s00531-006-0152-0

The category in the original version of this article unfortunately was wrong.

The correct category is "Original Paper".

The online version of the original article can be found under doi:10.1007/s00531-006-0152-0.

S. Branca $(\bowtie) \cdot$ M. Coltelli $\cdot$ E. De Beni Istituto Nazionale di Geofisica e Vulcanologia-Sezione di

Catania, Piazza Roma 2, 95123 Catania, Italy

e-mail: branca@ct.ingv.it

J. Wijbrans

Faculteit der Aardwetenschappen, Vrije Universiteit,

Amsterdam, The Netherlands 